\title{
AUTORISASJONSDOKUMENT RETT FRA SKRIVEREN
}

\author{
Statens autorisasjonskontor innførte 1. mars 2014 en ny ordning med elektronisk autorisasjonsdokument. \\ Helsepersonell med autorisasjon kan selv skrive ut autorisasjonsdokumentet når de ønsker det.
}

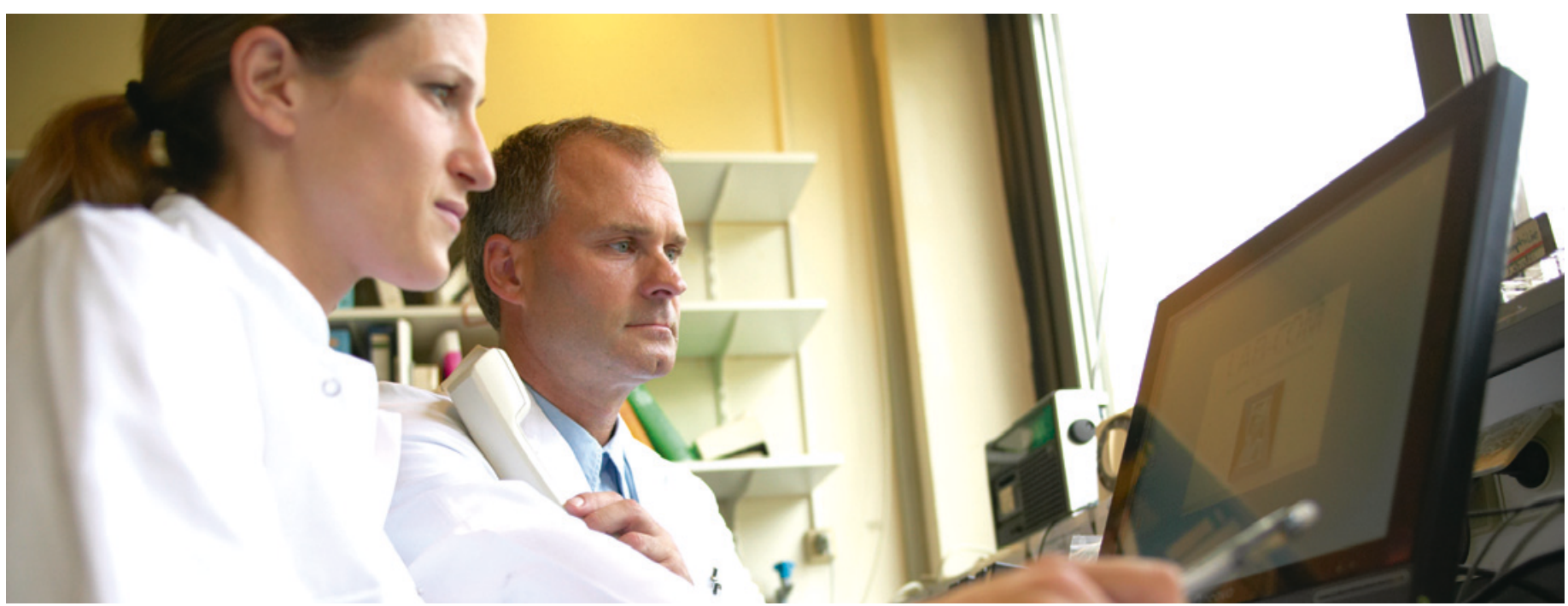

Foto: Jochen Sand/Thinkstock

Tidligere har helsepersonell fått utstedt og tilsendt et fysisk dokument fra Statens autorisasjonskontor som bevis på at de innehar autorisasjon for å praktisere som for eksempel lege. Denne ordningen er nå avviklet og erstattet med elektroniske autorisasjonsdokumenter (1).

Bakgrunnen for å avvikle den tradisjonelle ordningen med papirversjonen er blant annet at et skriftlig dokument i prinsippet bare er gyldig på utskriftstidspunktet. En autorisasjon er å regne som ferskvare, og med den nye ordningen kan helsepersonell selv hente ut en skriftlig bekreftelse på autorisasjonsstatus direkte fra registeret den dagen man trenger det. Utskriften vil være datert.

\section{Elektronisk helsepersonellregister} Helsepersonellregisteret er helsemyndighetenes register over alt helsepersonell med autorisasjon eller lisens etter helsepersonelloven, og veterinærer med autorisasjon eller lisens etter dyrehelsepersonelloven. Som erstatning for det fysiske autorisasjonsdokumentet er det utarbeidet et nytt elektronisk helsepersonellregister. Registeret er åpent for alle, og det er mulig å søke opp helsepersonell ved hjelp av fødselsdato, navn eller helsepersonellnummer. Helseper- sonellregisteret ligger på autorisasjonskontorets hjemmeside https://hpr.sak.no/hpr/.

Registeret inneholder en oppdatert oversikt over alt autorisert helsepersonell til enhver tid. Her får man opplyst korrekt autorisasjonsstatus uansett hvor lenge det er siden autorisasjonen ble gitt. Registeret inneholder opplysninger om gjeldende autorisasjon, lisens og forskrivningsrett, og eventuelle begrensninger i disse. Det oppgis også eventuell spesialitet for leger, tannleger og optikere. Den nye ordningen vil også gjøre det enkelt for arbeidsgiver å kontrollere at autorisasjonen er i orden.

Statens autorisasjonskontor for helsepersonell (SAK), tidligere forkortet SAFH, er en statsetat som tildeler autorisasjon og lisens til helsepersonell, og organiserer turnustjeneste for helsepersonell. Autorisasjonskontoret er underlagt Helsedirektoratet.

\section{Hanne Støre Valeur}

Tidsskriftet

\section{Litteratur}

1. Statens autorisasjonskontor for helsepersonell. Nå kan du selv skrive ut en bekreftelse på din autorisasjonsstatus. http://sak.no/sites/SAK/ om-sak/nyheter/Sider/sak-tar-ibruk-elektroniskautorisasjonsdokument.aspx (19.3.2014).
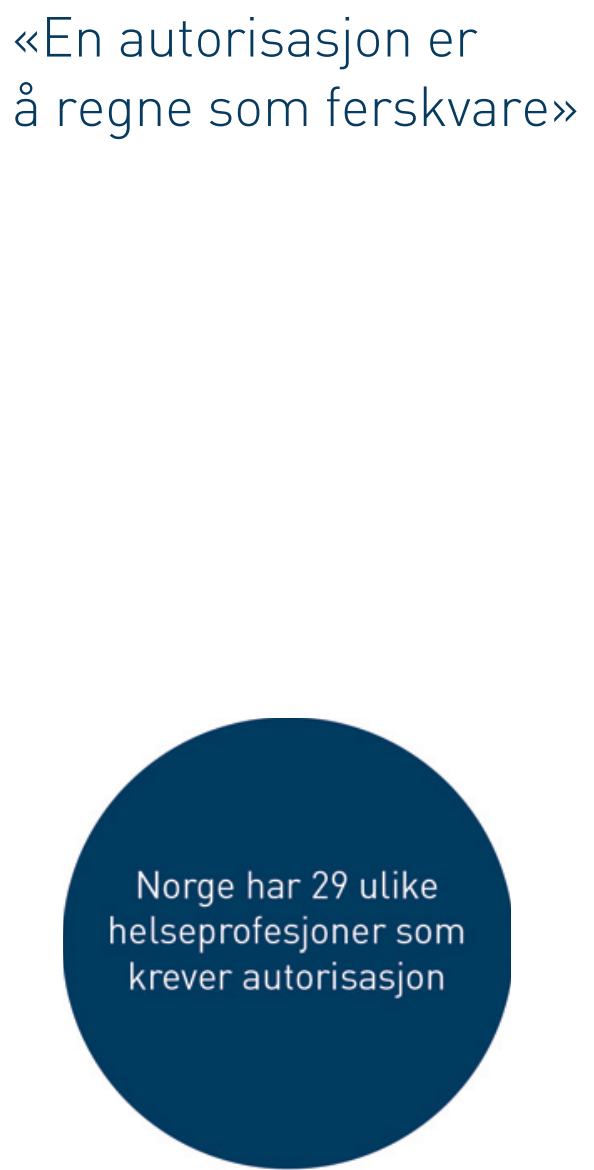